Reprinted from CROP SCIENCE

Vol. 17, May-June 1978, p. 362-364

Genetic Male Sterility in Pigeon Pea

Belum V. S. Reddy, John M. Green, and S. S. Bisen 


\title{
Genetic Male Sterility in Pigeon Pea
}

\author{
Belum V. S. Reddy, John M. Green, and S. S. Bisen²
}

\section{ABSTRACT}

Six malesterile plants, found in two apparently unre. lated sources in pigeon pea (Cajanus cajon (L.) Huth) did not produce polien. Crowing success was normal, indl. cating that the plants were lemale-fertle. White tranelucent anther color diatinguished malesterile plants from fertile plants, which had yellowith anthers. A single recesulve allele was responsible for the male uterility de. mcribed here. Study of microsporogeneats revealed that tetrads in male sterile plants did not separate and they completely disintegrated. The tapetum and the inter. cellular wall of the two adjacent microsporangia pervibted in the mature anthers. The potential value of male iterility in breeding programs is indicated.

Additional index words: selfing, Microsporogenesis, Male gametophyte, Tapetum.

PIGEO

IGEON pea (Cajanus cajan L. (Huth) is a food legume grown in almost all tropical countries. Nost of the acreage is planted to local landraces. While its floral biology appears to favor self-pollination, insect pollen vectors are sufficiently effective to put pigeon pea in the category of "often cross-polli. nated crops." Sufficient heterozygosity exists to permit differentiation of the local landraces in different environments, and to make each landrace a potentially rich gene pool.

Recognizing the utility of male sterility in popula. tion breeding and possibly in commercial hybrid seed

'Contribution from the IIIt. Crops Ren. Inst. for the Semi. Arid Troplew, Hyderubad-500016, Indla. Publinhed with the ap. proval of the Director. Received is July 1977.

- Plant breeder; Icader, Pulac Improvement Program; and plant anatomist, respectively. production, we made a deliberate search for male-sterile plants in 3,659 germplasm collections and 3,557 sublines grown at ICRISAT in 1974. A total of 72 plants were found with reduced pod set, and these could be classified into five aberrant floral types (Reddy et al., 1977). While all five types are being inaintained, we have concentrated our efforts on the one in which the only floral abnormality was absence of pollen. To our knowledge, male sterility had not been found previously in pigeon pea. Sterile plants reported by Deshmukh (1959) were apparently femalesterile.

\section{MATERIALS AND METHODS}

Six male-sterile plants that appeared identical in their flower morphology were found in two apparently unrelated sources. Those identified as MS.9.1 to F were found in ICP.1555 and iwo of fen sublines that had been scparated on the basis of seed color. IC.P.1555 had been collected in . Indhra Pradesh, India. MS.4.1 wнy in ICP.1596, a collection from Maharashtra.

Because of the incleterminute nature of flowering in the two vourcen, it was possible to utilize flowels on the original plants for varlous mtulies. From each plant three to flve buds were flxed in $7.5 \%$ alcohol and the anthers nqueezed in $2.2 \%$ aceto orcein stain for microncopic exumination for the presence of pollen. .III plaits were further tested for pollen presence by covering an entire branch with a cloth bag (after removing pods and prevlously opened flowerw) and by covering budi with glassine bagn.

kach male-uterilc plant wиx cromed with eight normal parents that were diverac in origin and maturity. Each male sterile was also sjbbed with fertile plants withill the row, but unfortu. nately. male parents werc not identified Indlvidually, to mean. Ingful data could not be obtained from these sib progenies. Open-pollinatcel reed was collected fiom the liddividual fertile plants within cach row. 

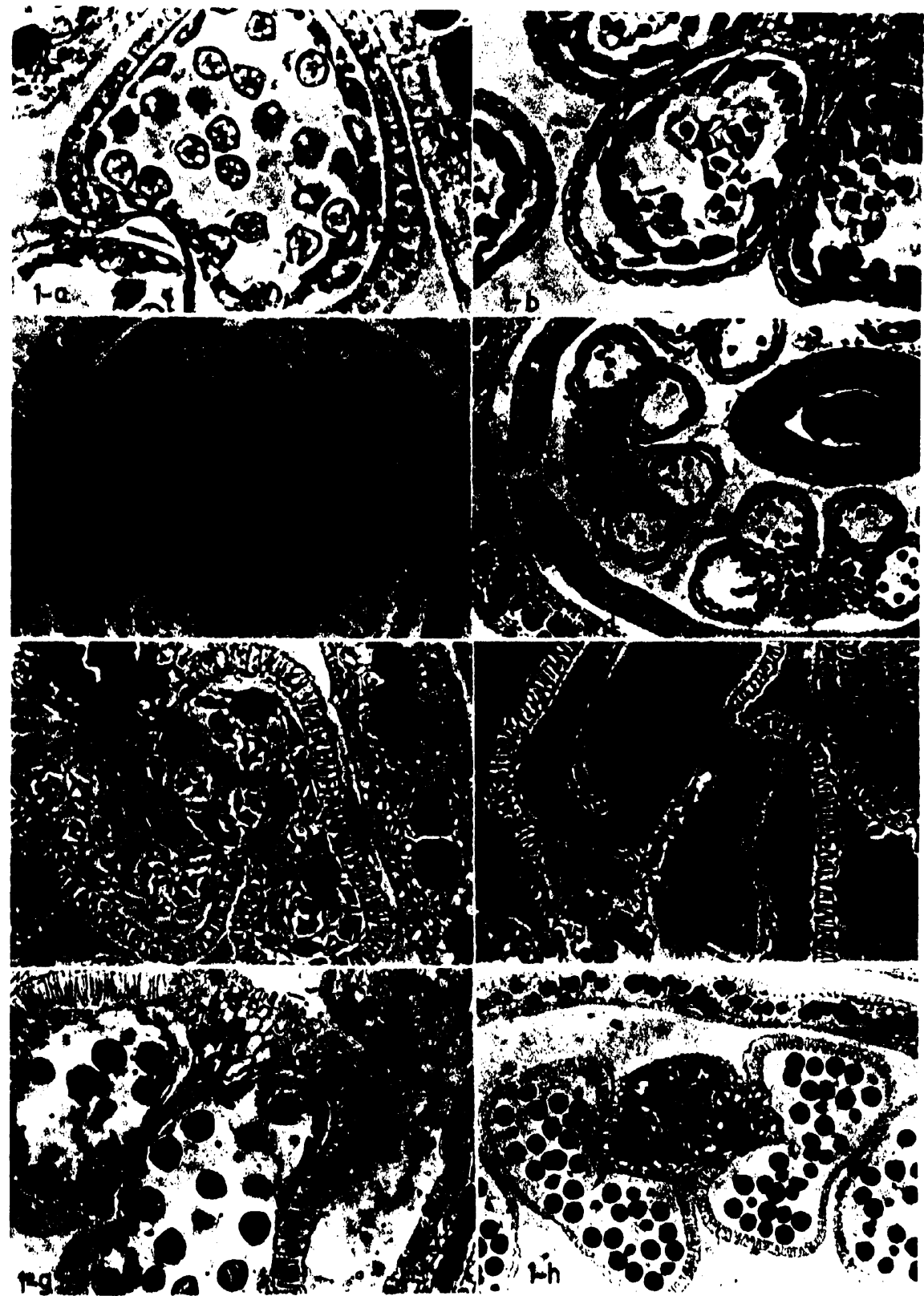

It. 1. Development of male gametophyte in fertile and male aterlle anthers of pigeon pea. 1a. Tetrads $(160 \times)$ in fertile. $1 \mathrm{~b}$. Te trada $(160 X)$ In malesterile. Ic. Immature male gametophytes $(40 X)$ In fertlle. Id. Immature male gametophytes (40X) in male uterile. le. Detenerated male gametophyte within the apore mother-cell uac $(160 x)$ in male aterile. If. Completely degenerated male gametophytes and the peralutent tapetum $(160 \times)$ in male uterile. $1 \mathrm{~g}$. Release of male gametophytes from spore mother cell sac $(100 \times)$ In tertile. In. Complete developed male gametophytes $(160 x)$ and no trace of tapetum in fertile. 
In 1975 all the $F, s$, sibs. and progenies of fertile plants of the parent lines wete grown. Male-sterile plants were sibmated with individual fertile plants. In 1976 all $F$, is and sib progenies were grown and plants were classified for male sterility.

In the progeny of a fertile plant harvested in the subline 1555.2. which segregated for fertile and male sterile, buds were collected from male-sterile and fertile plants for comparative studies of microsporogenesis. Buils of various lengths up $10.5 \mathrm{~mm}$ were fixed in FP.A (70\% alrohol 90cs, formaldehyde 5cc, propionic acid $i(s)$ for at least 48 hours. After dehydration through an cthanol series followed by tertiary butyl alcohol, the buds werc cmberded in paraffin at 60 to $62 \mathrm{C}$. Transverse sections $10 \mu$ thick were hydrated aud stained with toludine blue 0 accord. ing 10 the procedure of O'Brien et al (1964). These were exam. ined under an ordinary light microscope and photomicrographs were made.

\section{RESULTS AND DISCUSSION}

The male-sterile plants were apparently morphologically identical to the fertile plants in each source culture in maturity, height, branching, leaf size, etc. The male-sterile plants were slower to senesce than the fertile plants, and they could be distinguished by their greener and more abundant leaves at normal harvest time. Brim and Young (1971) reported male-sterile soybean plants, (ilycine max (L.) Merr., were greener with thick leaves. It seems likely that in both species delaved senescence resulted from reduced pod set.

All llower parts, except anthers, were normal in size and color in the male-sterile plants. Their anthers were smaller than normal, flat, and translucent with whitish scaly surfaces. These anthers did not dehisce and they dried faster than the normal anthers. The inthers of sterile plants could be distinguished from the plump, yellowish normal anthers 3 to 4 days before anthevis. Differences in the appearance of anthers were used to distinguish male-sterile and fertile plants.

Pollen wals not observed in the anthers of any of the six original male-sterile plants when tested in acetoorcein stain. There was no pod setting on protected branches or buds of five of the male-sterile plants; on one plant, two of approximately 80 buds inside the cloth hag set pods. A progeny test indicated the seeds were hybrid. We assumed that either two open flowers or young pods werc not removed at the time of bagging or a bee entered through an undetected hole in the bag. The general failure of pod set upon selfing corroborates the absence of pollen. Self-incompatibility is not considered to be a factor, since wide-scale selfing in the germplasm collection has been successful.

Open-pollinated seed from the fertile plants in the two sonice cultures were planted in progenies. From the $115-3$ source (IC:P-1555) and sublines), 29 progenies were grown, of which 24 segregated for male sterility. Willin each progeny, the segregation fit a $3: 1$ ratio. For the 24 progenies pooled, there were 240 fertile and 78 malesterile plants with $p=0.75$ to 0.90 for goodness of lit $103: 1$. In the MIS.4 source, one of seven progenies segregated for 11 fertile to thrce male-sterile, ilso at good fit to $3: 1$.

Crosing succes on the male-sterile plants was normal, demonstrating female fertility. Of the 18 attempt(d) anser involving the six malesterile plants and eight normal patrents. 11 were successful. All $F$,'s were lettike, indicating dominance of the normal. In the
$F_{2}$ 's only one of the 41 combinations did not fit a 3:1 ratio. The total for all crosses was 2,243 normal to 737 male-sterile, $P=0.50$ to 0.75 for goodness of fit to $3: 1$. It seems safe to conclude that this male sterility is controlled by a single recessive gene. The symbol $\mathrm{ms}_{1}$ is proposed.

Microsporogenesis was similar in the fertile and male-sterile plants in the premeiotic and meiotic stage. Tetrad formation (Fig. la, b) was the latest stage observed in which fertile and sterile did not differ. After the formation of tetrads, the course of development differed in the sterile and fertile plants. Tetrads were released from the spore mother cell sac in the fertile plants (Fig. IC); in sterile plants (Fig. Id) the tetrads were not released, and they started degenerating by vacuolation (Fig. le). Later the tetrads degenerated completely, while the tapetum persisted (Fig. If). By contrast, in the normals the tapetum started degenerating at the time of tetrad formation, and during male gametophyte development no tapetum remained (Fig. Ig, h).

The cause for failure of pollen development in the male-steriles cannot be inferred from the data presented here. Persistent tapetal cells in male-sterile plants have been reportd in Allium by Singh and Kobabe (1969), in orchardgrass (Dactylis glomerata L.) by Filion and Christie (1966), and in barley (Hordeum vulgare L.) by Kaul and Singh (1966). Degeneration of tetrads while in the spore mother cell sac as observed in this study was reported in two-row barley by Kaul and Singh (1966). They reported release of microspores before degeneration in six-row barley, and Filion and Christie (1966) reported release of the tetrads in Dactylis before degeneration occurred.

Our staining and cytological studies showed that the mutant plants were completely male-sterile. The inheritance studies indicated that the male sterility is governed by a single recessive allele. The visible marker, white translucent anther color, provides an efficient and fast way of recognizing these plants in the field. Further, pod setting on male sterile plants under open pollination appears to be adequate for seed production. Therefore, the male sterility reported here is considered potentially useful in the production of hybrids and in population improvement programs.

\section{REFERENCES}

Brim, C. A., and M. F. Young. 1971. Inheritance of a male-sterile characier in soybeans. Crop Sci. 11:564.566.

Deshmukh. N. Y. 1959. Sterile mutants in Tur (Cajanus cajan). Nagpur Igric. Coll. Mag. 33:20-21.

Filion, W'. G., and B. R. Christic. 1966. The mechanism of male sterility in a clone of orchard grass (Daclylis glomerata $L_{\text {. }}$ ). Crop Sci. 6:345-347.

Kaul. C., L., and S. P. Singh. 1966. Studies in male-sterile harley. 11. Pollen abortion. (rop Sci. 6:539-541.

O'Bricn, T. '', N. Feder, and M. E. McCully. 1964. Polysomatic staining of plant cell walls by Toludine Blue 0 . Proto. plasma : 9:306-373.

Recdily, H. V. S.. I.. J. Rerddy, and 1. N. Murthi. 1977. Reproduc. live variants in Ciajumu rajan (I..) Millsp. Trop. Grain Legume Bull. No. 7:11.

Singh, V. '., and (. Kobalx, 1969. Cyto-morphological investiga. tion on inale sterility in Allium schomoprasum L. Indian J. (ienet. 29:241.247. 